\title{
Reflection in Action: A Key to Developing Competences for the Teaching of Science
}

\author{
By Antonio Fernández-Crispín* \\ María Estela Ruiz Primo ${ }^{\dagger}$ \\ Ana Cecilia Tapia Lobatón ${ }^{*}$ \\ José Praxedis Amaro Olivera ${ }^{+}$ \\ Armando Noé Rodríguez Galván ${ }^{+}$
}

The aim of this research was to identify and analyse the concepts and ideas related to the nature of science, scientific concepts, and teaching and learn about science developed by a group of teachers during a training course for the teaching of sciences skills. The educational strategy was developed from a critical position on the expository models and guided discovery. Teachers assumed the role of students, reflecting on their learning and teaching and, eventually, rebuilding this learning situation with their students. In conclusion, the workshop promoted a conceptual change related to the topics and subjects addressed in the classroom: teachers' and the students'ideas related to learning about science; the evaluation of teaching; the development of creative and critical thinking; and, the development of scientific tools. Overall the teachers enjoyed the course and reoriented their approach to working in the classroom.

Keywords: flipped classroom, formative assessment, reflection in action, science education, science teacher training

\section{Introduction}

Elementary education in Mexico comprises two years of kindergarten (4-6 years old), six years of primary school and three years of junior high school. According to the Ministry of Public Education (SEP), in 2013 there were $14,909,419$ students studying elementary education in Mexico. These students are educated by 573,849 teachers in 99,378 schools under very heterogeneous conditions (SEP, 2013).

While the SEP has made efforts to achieve near universal coverage in basic education, the results of international and national assessments as: Programme for International Student Assessment - PISA (OECD, 2012) and National Assessment of Academic Achievement in School Centres (ENLACE)

\footnotetext{
*Professor, Benemerita Autonomy University of Puebla, Mexico.

${ }^{\dagger}$ Retired Professor, Benemerita Autonomy University of Puebla, Mexico.

Student, University of Guadalajara, Mexico.

${ }^{+}$Professor, Benemerita Autonomy University of Puebla, Mexico.
} 
(SEP, 2014) indicate that there is still much to do to improve the quality of education.

Based on the latest (2012) PISA results, in which Mexico scored 76 points below the average of other OECD (Organisation for Economic Cooperation and Development) countries, the OECD recommends that efforts are focused on increasing the number of students reaching basic levels of competence as well as on the promotion of excellence. The OECD also recommends not only the improvement of training programs and teacher training, but also the creation of a coherent system of technical and vocational training that emphasizes teaching quality and improves the certification of knowledge. These changes must be accompanied by a well conceived and rigorously applied evaluation system (OECD, 2012).

Based on the OECD recommendations, here in the state of Puebla in Mexico, the state government and SEP signed an agreement with the Faculty of Biology at the BUAP to train primary school teachers in the area of natural science.

The project commences with the idea that teachers are the real agents of curriculum development. The goal is to promote the participants' reflective action (metacognition) that allows them to reflect on their experiences as teachers and strengthen them through the observation, analysis and comparison of processes in order that they are able to design, conduct and evaluate new teaching strategies. Our aim is that teachers contribute to the formation of scientific thought in their students, so that they are able to identify and solve problems in both science and everyday life.

Focusing on training good teachers (Oppenheimer, 2011), we hope to contribute to the development of the disciplined, synthetic, creative, respectful and ethical thinking proposed for the future of education by Gardner (2007), and the seven pieces of knowledge required for the future, as described by Morin (1999).

The objective of this research was to identify and analyse the concepts and ideas related to the nature of science, scientific concepts, and teaching and learn about science developed by a group of teachers during a training course for the teaching of sciences skills.

\section{Theoretical Framework}

Schmelkes (1997) mentions that in many Mexican schools, learning experiences are monotonous, with activities such as reading or copying texts, or carrying out exercises either dictated by the teacher or written on the blackboard. The predominant teaching model is focused on the teacher, oriented to the group as a whole, based on the textbook as the sole source of information and practice, and supported using the blackboard as the only teaching resource. Tirado (1990) adds that the curricula are disproportionate in terms of the amount of content, while Guevara (1991) also mentions that school practices are boring and tedious, and destructive for the child's curiosity 
and imagination.

To overcome this problem, a pedagogical model is proposed that goes beyond the idea of the student as a scientist to consider them as an apprentice, and, thus, coming from a critical position toward the expository models and through guided discovery, intends to regain their strengths and overcome their weaknesses (Marin, 2005). The teacher is conceived as a manager of learning environments located in specific contexts. The pedagogical principles guiding the course are as follows: a. previous ideas; b. the flipped classroom (Alvarez, 2012); c. joint action; d. reflection-in-action; (Schön, 1987) and, e. formative assessment.

The principal educational strategy is that teachers assume the role of students and reflect on their learning and teaching and eventually rebuild this learning situation with their students. With this, it is intended that teachers rediscover the importance of practical learning by flipping the traditional pattern of teaching, which consists of assigning textbooks for the students to read and then working on sets of problems outside school, while listening to lectures and taking tests in class. Instead, in the model proposed, the students first study the topic by themselves, and then, in class, apply their knowledge by solving problems and doing practical work (Keengwe, Onchwari, \& Oigara, 2014).

By means of formative assessment, both reflection on activities and metareflection is encouraged. Thus, teachers will develop skills and strategies to detect the conceptual difficulties involved in the problems to be taught (from an academic point of view), the difficulties involved in student understanding (preconceptions, alternative ideas, misconceptions) and how to address them in class. At the same time, they reflect on the scientific skills that the various topics allow us to develop, from measuring, estimating, serializing and classifying, to the development of deductive hypothetical thinking, which includes combinatorial thinking, the identification and control of variables, and proportional thinking (Lawson, 1995).

\section{Methodology}

The strategy followed in this project basically involves three steps: a. diagnosis of critical situations and needs; $b$. design and implementation of the educational strategy; and, c. evaluation.

\section{Design and Implementation of the Educational Strategy}

The curriculum defines the content and activities found in the textbooks that are published by the SEP and distributed free of charge to all elementary students. Since these books are the basic tool for working in the classroom, a comprehensive review of the activities they suggest was made, with the intention of choosing the most appropriate ones for the teacher training course. 
Particular focus was placed on activities related to the topics in which major problems have been detected through various assessment instruments. The activities chosen enable the following: a. the development of scientific skills (observation, identification of relationships, the formation of hypothesis, experimentation, interest in and knowledge of the natural world, organizing concepts and communication); b. the development of mental structures; $c$. the understanding of science as a process of inquiry; c. the development of concepts through preconceptions; and, $d$. the provision of educational tools for teachers.

In addition, a review of educational research articles was conducted, in order that more could be gotten out of textbook activities, with an activity with conceptual errors and another very simple activity chosen to show how to improve them, as supported in this study by the bibliography.

The course consists of 10 sessions of 4 hours. Based on that proposed by Lawson (1995), Driver and Oldham (2000), Guevara and Fernández- Crispín (2010). The plan of activities resulting from this analysis is presented in Table 1.

The aims of the course are as follows:

- Teachers will expand their knowledge of the natural science curriculum and develop teaching skills to increase their students' academic achievement as measured by the ENLACE tests.

- Teachers will develop pedagogical skills so that students will be able to describe, infer, explain, predict, collect and interpret data, analyse, search for information, argue, discuss and refute, as important processes for the conduct of science.

- Teachers will promote competencies and skills for action at an individual and collective level, as well as team work and the respect for the opinions of others.

In order to foster better communication, a Moodle platform ${ }^{1}$ was used. This is a resource for managing self-learning, group learning and personalized learning that is flexible and attractive to the teacher in order that they can explore different websites or resources independently. Furthermore, spaces to exchange, receive and send information in different electronic formats are promoted.

\footnotetext{
${ }^{1}$ bit.ly/22tvVeM.
} 
Table 1. Plan of Activities

\begin{tabular}{|c|c|c|c|c|c|c|c|}
\hline Session & Theme & Strategy & SI & DMS & DCT & ST & PT \\
\hline 1 & $\begin{array}{l}\text { How did we know } \\
\text { this? The scientific } \\
\text { knowledge }\end{array}$ & $\begin{array}{l}\text { The seasons of the year } \\
\text { Shadow Theater The sun } \\
\text { clock. }\end{array}$ & $\mathrm{X}$ & & $X$ & $\mathrm{X}$ & $\mathrm{X}$ \\
\hline 2 & $\begin{array}{l}\text { Properties of the } \\
\text { materials }\end{array}$ & $\begin{array}{l}\text { Scales. Volume. } \\
\text { Properties of the } \\
\text { materials .Plastic or } \\
\text { paper. Identify } \\
\text { properties of toilet paper } \\
\text { (durability, elasticity and } \\
\text { strength) }\end{array}$ & $\mathrm{X}$ & $\mathrm{X}$ & & $\mathrm{X}$ & $\mathrm{X}$ \\
\hline 3 & The human body & $\begin{array}{c}\text { Manufacture of a } \\
\text { mechanism that explains } \\
\text { the functioning of the } \\
\text { lungs }\end{array}$ & & & $X$ & & $\mathrm{X}$ \\
\hline 4 & Nutrition & The correct diet & & $\mathrm{X}$ & $X$ & $\mathrm{X}$ & $\mathrm{X}$ \\
\hline 5 & Reproduction & $\begin{array}{l}\text { Food for growth. Seed or } \\
\text { plant? Similarities and } \\
\text { differences between } \\
\text { sexual and asexual } \\
\text { reproduction. Everyone } \\
\text { depends on everyone. }\end{array}$ & & & $\mathrm{X}$ & $\mathrm{X}$ & $\mathrm{X}$ \\
\hline 6 & $\begin{array}{l}\text { How to name so } \\
\text { many different } \\
\text { lifeforms. } \\
\text { Biodiversity and } \\
\text { classification }\end{array}$ & $\begin{array}{c}\text { The causes of viruses, } \\
\text { bacteria, fungi and } \\
\text { plagues. }\end{array}$ & & $X$ & & $\mathrm{X}$ & $\mathrm{X}$ \\
\hline 7 & $\begin{array}{l}\text { Biotic and abiotic } \\
\text { factors }\end{array}$ & $\begin{array}{l}\text { Biodiversity of where I } \\
\text { live. Food chains. }\end{array}$ & $\mathrm{X}$ & & $\mathrm{X}$ & $\mathrm{X}$ & $\mathrm{X}$ \\
\hline 8 & Evolution & $\begin{array}{c}\text { Write a comic strip } \\
\text { about Darwin and how } \\
\text { he came upon the theory } \\
\text { of evolution }\end{array}$ & $\mathrm{X}$ & $\mathrm{X}$ & $X$ & $X$ & $X$ \\
\hline 9 & $\begin{array}{l}\text { Climate change, } \\
\text { Recycling, } \\
\text { Responsible } \\
\text { consumption }\end{array}$ & Ecological footprint & & & & & $\mathrm{X}$ \\
\hline 10 & $\begin{array}{c}\text { Cycle of science } \\
\text { conferences }\end{array}$ & & & & & & $\mathrm{X}$ \\
\hline
\end{tabular}

SI: Science as inquiry; DMS Development of mental structures; DCT: Development of concepts through (previous ideas); ST: Scientific tools and PT: Pedagogical tools.

\section{Evaluation}

The formative assessment consisted of a portfolio that included a scientific dictionary, a research diary and projects undertaken with their students. The portfolio analysis provides insight into how teachers structure their thinking and incorporates new concepts and teaching strategies. The portfolios were delivered in the Moodle platform. 
Portfolios. The portfolio is an educational strategy and a skills assessment that is based on the collection and organization of a body of evidence in a folder to show the achievement of one or more learning outcomes, taking into account the improvement attained during the process (Tobón, 2004). The portfolio of this course includes, at least, the following elements:

- Scientific Dictionary: In which the key concepts are identified and explained simply and clearly, using an example and an illustration. The aim is that the word actually has a meaning for those who use it.

- Research diary: A tool that enables the organization and systematization of the information generated during the session. It is a guide to propose research projects, as well as providing follow-up. It also serves as a record of the learning progress attained by every teacher in the sessions and throughout the entire course. Meta-reflexion should be stimulated $i e$, the teacher reflects on how they learned. This includes, at least, answers to the following questions:
a. Date and name of the session
b. Describe in general terms what was carried out during the day, emphasizing the different teaching strategies.
c. What did I learn in this session?
d. Why do I think I learned it?
e. Which teaching strategies did I like the most?
f. Which teaching strategies did I like the least?
g. What is my opinion about the readings for the session?
$\mathrm{h}$. What differences and similarities are there between the activities of the session and my traditional way of teaching?
i. How can I improve my class in terms of the issues that were covered in this session?

- Research Projects: Teachers are invited to undertake with their students the activities they performed in the course and then deliver a report. By the end they must have undertaken at least three of such activities with their students. These activities have as an objective the development of scientific skills and the capacity to plan and organize ideas.

- Final Project: During the course, teachers form teams to carry out a project that enables the integration and application of learning. The development of the project demands a gradual advance as accompanied by the mediators. It is important that the teacher undertakes the project with their students and presents a report.

\section{Portfolio Assessment}

The analysis of ideas and opinions expressed in the various instruments of the portfolio reveals the processes of reflection and meta-reflexion of those 
teachers who attended the course, as well as the concepts and skills they acquired. Observation rubrics were drawn up in order to analyse the level of scientific and pedagogical skills (Table 2). In this case, we analyse the observations reported in the research diary as well as the final project report.

Table 2. Final Project Observation Rubric

\begin{tabular}{|c|c|c|c|}
\hline & $\begin{array}{c}\text { Level } 1 \\
\text { Initial - receptive }\end{array}$ & $\begin{array}{l}\text { Level } 2 \\
\text { Basic }\end{array}$ & $\begin{array}{c}\text { Level } 3 \\
\text { Autonomous }\end{array}$ \\
\hline $\begin{array}{l}\text { 1. Generation of } \\
\text { sociocognitive } \\
\text { conflict. (generating } \\
\text { question) }\end{array}$ & $\begin{array}{l}\text { Closed questions were } \\
\text { asked. These were } \\
\text { related to the content } \\
\text { but did not identify } \\
\text { prior knowledge, nor } \\
\text { did they promote a } \\
\text { conceptual change. }\end{array}$ & $\begin{array}{l}\text { Open questions were } \\
\text { asked. These were } \\
\text { related to the content. } \\
\text { These questions } \\
\text { promote interest in the } \\
\text { subject, as well as the } \\
\text { reflection and } \\
\text { recognition of prior } \\
\text { knowledge. } \\
\text { The question did not } \\
\text { permit relationships to } \\
\text { be established and only } \\
\text { promoted knowledge. }\end{array}$ & $\begin{array}{c}\text { Beyond the prior levels, } \\
\text { the question promotes } \\
\text { procedures, such as } \\
\text { explanations (for } \\
\text { what?) or strategies } \\
\text { (with what or where?) }\end{array}$ \\
\hline $\begin{array}{l}\text { 2. Presentation of } \\
\text { initial ideas }\end{array}$ & $\begin{array}{l}\text { A climate of respect } \\
\text { and trust is created, } \\
\text { which motivates the } \\
\text { participation of some } \\
\text { members of the group. }\end{array}$ & $\begin{array}{l}\text { Beyond the previous } \\
\text { level, ideas are } \\
\text { organized } \\
\text { squematically (graphs, } \\
\text { tables, drawings, etc.) }\end{array}$ & $\begin{array}{c}\text { Beyond the previous } \\
\text { level, relationships } \\
\text { between prior ideas are } \\
\text { established. }\end{array}$ \\
\hline 3. Analysis & $\begin{array}{l}\text { Each group member's } \\
\text { ideas are contrasted } \\
\text { with those of the others. }\end{array}$ & $\begin{array}{c}\text { Beyond the previous } \\
\text { level, the contradictions } \\
\text { between previous ideas } \\
\text { (at different levels of } \\
\text { conceptualization) are } \\
\text { recognized, and } \\
\text { cognitive conflict made } \\
\text { evident. }\end{array}$ & $\begin{array}{l}\text { Beyond the previous } \\
\text { level, the processes and } \\
\text { different complexity } \\
\text { levels of the } \\
\text { explanations are } \\
\text { recognized. }\end{array}$ \\
\hline $\begin{array}{l}\text { 4. Search for } \\
\text { information }\end{array}$ & $\begin{array}{c}\text { This only interests itself } \\
\text { in oral or audio-visual } \\
\text { information. }\end{array}$ & $\begin{array}{l}\text { The search for } \\
\text { information is promoted } \\
\text { through one of the } \\
\text { following media: the } \\
\text { revision of the } \\
\text { bibliography, the } \\
\text { internet, the } \\
\text { experiments, etc. }\end{array}$ & $\begin{array}{l}\text { The search for } \\
\text { information is promoted } \\
\text { through one of the } \\
\text { following media: the } \\
\text { revision of the } \\
\text { bibliography, the } \\
\text { internet, the } \\
\text { experiments, etc. }\end{array}$ \\
\hline $\begin{array}{l}\text { 5. Organization } \\
\text { (reconstruction) }\end{array}$ & $\begin{array}{l}\text { New information is } \\
\text { used and organized, } \\
\text { thus establishing } \\
\text { relationships. }\end{array}$ & $\begin{array}{c}\text { Beyond the previous } \\
\text { level, new information } \\
\text { is contrasted with prior } \\
\text { ideas. }\end{array}$ & $\begin{array}{l}\text { Beyond the previous } \\
\text { level, new concepts are } \\
\text { restructured. }\end{array}$ \\
\hline $\begin{array}{l}\text { 6. Production of a } \\
\text { final piece of work. } \\
\text { (Applied to } \\
\text { everyday situations) }\end{array}$ & $\begin{array}{c}\text { That which has been } \\
\text { learned is not related to } \\
\text { everyday life. }\end{array}$ & $\begin{array}{c}\text { That which has been } \\
\text { learned is related to } \\
\text { everyday life, but not } \\
\text { applied. }\end{array}$ & $\begin{array}{c}\text { That which has been } \\
\text { learned is related to } \\
\text { everyday life, and also } \\
\text { applied. }\end{array}$ \\
\hline
\end{tabular}




\section{Results and Discussion}

A content analysis was made of the Research diaries for sessions 1, 5 and (Table 3). This analysis shows that the most frequent scientific tools promoted by teachers were observation, communication of research findings and identification of relationships. As hypothesis formulation was not encouraged, practical activity, which they call "experiments", is reduced to the taking of data and interpretation of that which has been observed. The observations of the practical results were not compared to previous ideas, which, thus, do not favour a conceptual change.

Almost all works are planned and structured, promoting the organisation of concepts, teamwork and, hence, joint action. They partially incorporate evaluation as part of the process to encourage reflection-in-action.

The course promotes both interest in the natural world and knowledge of it, but the great achievement of this course was that teachers recognized the importance of practical work and expressed their desire to apply it more often, as part of a double process. First they enjoyed and learned through practical work, and second, because when they did so, these students worked with more pleasure, freedom and creativity, something which the teachers also enjoyed, rediscovering how fun it can be to listen to children's ideas.

Table 3. Content Analysis of the Research Diaries at the Beginning, Middle and End of the Course

\begin{tabular}{|l|c|c|c|}
\hline & $\begin{array}{c}\text { Session 1 } \\
\mathbf{\%}\end{array}$ & $\begin{array}{c}\text { Session 5 } \\
\mathbf{\%}\end{array}$ & $\begin{array}{c}\text { Final } \\
\mathbf{\%}\end{array}$ \\
\hline Scientific tools employed & & & \\
\hline Observation & 100.0 & 100.0 & 90.5 \\
\hline Identification of relationships & 5.9 & 91.7 & 85.7 \\
\hline Hypothesis formulation & 0.0 & 0.0 & 0.0 \\
\hline Experimentation & 0.0 & 95.8 & 90.5 \\
\hline Interest in and knowledge of the natural world & 5.9 & 100.0 & 90.5 \\
\hline Organization of concepts & 35.3 & 70.8 & 90.5 \\
\hline Communication & 100.0 & 100.0 & 90.5 \\
\hline Pedagogical tools employed & & & \\
\hline Goal & 0.0 & 70.8 & 66.7 \\
\hline Evaluation & 0.0 & 12.5 & 23.8 \\
\hline Cognitive conflict & 0.0 & 0.0 & 9.5 \\
\hline Previous knowledge & 0.0 & 58.3 & 52.4 \\
\hline Cooperative learning & 94.1 & 100.0 & 90.5 \\
\hline Passive learning & 94.1 & 75.0 & 4.8 \\
\hline Discovery learning & 0.0 & 12.5 & 81.0 \\
\hline Guided learning & 0.0 & 8.3 & 4.8 \\
\hline Learning from previous ideas & 0.0 & 0.0 & 0.0 \\
\hline Situated learning & 0.0 & 0.0 & 0.0 \\
\hline Meaningful learning & 5.9 & 4.2 & 4.8 \\
\hline
\end{tabular}

The table shows the percentage to which different scientific and pedagogical tools are mentioned or used. 
Teachers presented 11 final projects that they designed in teams, and then applied each one with their students. The preferred theme was nutrition (5 projects), with two others being related to biodiversity. Further work on reproduction, the ecological footprint, electricity and human anatomy was also presented. In most projects, the idea of science as a form of inquiry is promoted, although science is still seen as a source of information. In other cases, projects applying science arose. Again, almost all works are planned and structured, promoting teamwork and, hence, joint action; but this time, they also incorporate evaluation as part of the process to encourage reflection-inaction.

According to the observation rubric, final projects go beyond the receptive level to pass to the basic level, but did not reach the autonomous level. In these projects, it is known that the questions generated must be closed in relation to content, neither by identifying prior knowledge nor by promoting conceptual change. They only promote the acquisition of knowledge, interest in the subject, reflection and recognition of prior knowledge, but do not allow relationships to be established. This is despite the fact that in the research diaries, the teachers constantly talk about the importance of previous ideas.

On the presentation of previous ideas, they created a climate of trust and respect that encourages participation in the group. They organized ideas schematically but did not establish relationships. To promote analysis of these ideas was the weakest point, as it was difficult to contrast the ideas of each group member with the others and did not identify the contradictions with prior ideas.

They promoted the search for information by various means on an autonomous level. Regarding the organization of new information, they have many tools. Although conceptual maps were most often used, conceptual changes were not identified. Finally, they have a very practical attitude and always tried to apply learning to everyday life.

The goal that was not achieved was working with previous ideas. We assume that there are some conceptual and epistemological obstacles to conceive education as a process of conceptual change from previous ideas (Hewson \& Hewson, 1989). According to Da- Silva et al. (2007) teachers have very ingrained ideas about the nature of science, scientific concepts and how to teach and learn science that could take many years to change. Teachers still have an empiricist view of science that is dogmatic and absolute, decontextualized, linear and cumulative, and rigid and algorithmic. They believe that to teach science is to transmit knowledge, and that a good experiment alone can teach (Marin, 2005). They also believe that to research is to collect data. Moreover, teachers believe that the methods of science education should be active, even though they always find some reason or excuse for not making it so (Fernández- Crispin, 2002).

Marín (2005) believes that the training of a science teacher goes through various levels. In the first level, only declarative knowledge is taught and resources are used in isolation. In the second, teachers are no longer limited to 
oral presentation and start mechanically using strategies, including some "experiments". In the third, teachers begin to design their own activities, try to promote procedural skills, enable the transfer of knowledge gained outside the academic environment, try to overcome the erroneous views of science, and, especially, enable the improved development of concepts. At the fourth level, teachers can provide solutions to well-founded problems and go beyond traditional views of science and how it is taught and learned. Under this framework, we consider that, in the beginning, course attendees were on the first level. By the end of the process, some teachers have moved to the second level, the majority to the third and practically none to fourth. However, considering that the course lasted 10 weeks, the development seen here is a good achievement.

\section{Conclusion}

At the end of the course, participants still saw science as a source of information; however the idea of science as a form of inquiry was promoted. The course promoted a conceptual change on course topics, teachers' and their students' ideas related to the learning of science, teaching and evaluation and the development of creative and critical thinking. Although, the course promoted the development of scientific tools such as observation, the identification of relationships, experimentation, interest in the natural world, the organization of concepts and the communication of research findings, however it did not the formulation of hypothesis. Overall, teachers enjoyed the course and were able to reorient the way they work in class, giving more priority to practical and collaborative work, formative assessment and reflective action. The key to success was that teachers assumed the role of students, reflected on their own learning and teaching, and finally rebuilt this learning situation with their students.

\section{References}

Alvarez, B. (2012). Flipping the Classroom: Homework in Class, Lessons at Home. Education Digest: Essential Readings Condensed for Quick Review, 77(8), 18-21.

Da-Silva, C., Mellado, M., Ruiz, C., \& Porlán, R. (2007). Evolution of the conceptions of a secondary education biology teacher: longitudinal analysis using cognitive maps. Science Education, 91(3), 461-491.

Driver. R., \& V. Oldham (2000). Un enfoque constructivista del desarrollo curricular en ciencias [A constructivist approach to curriculum development in science]. In Porlan R., J.E. García, \& P. Cañal (Eds.), Constructivismo y enseñanza de las ciencias. Sevilla: Diada EditorialS.L.

Fernández-Crispín A. (2002). Análisis del modelo de educación ambiental que transmiten los maestros de primaria del municipio de Puebla (México) [Analysis of the model of environmental education transmitted by elementary school teachers at the municipality of Puebla (Mexico)] Doctoral dissertation. Universidad Autónoma de Madrid. Madrid, Spain. 
Gardner, H. (2007). Five Minds for the Future. Boston: Harvard Business School Press.

Guevara M- J., \& Fernández-Crispín, A. (2010). Conocimientos y actitudes ambientales en primaria. Dos décadas de educación ambiental en México [Knowledge and environmental attitudes in elementary school. Two decades of environmental education in Mexico]. Puebla: UPAEP.

Guevara, G. (1991, June). México: ¿Un país de reprobados? [Mexico: a country of flunkers?]. Nexos, 162, 33-44.

Hewson, P. W., \& Hewson, M. G. (1989). Analysis and use of a task for identifying conceptions of teaching science. Journal of Education for Teaching, 15(3), 191 209.

Keengwe, J., Onchwari, G., \& Oigara, J. N. (Eds.). (2014). Promoting Active Learning Through the Flipped Classroom Model. Hershey, PA: IGI Global.

Lawson A. (1995). Science teaching and development of thinking. Belmont, CA.: Wadseorth Publishimg Company.

Marín, N. (2005). La enseñanza de las ciencias en educación infantile [The teaching of science in early childhood education]. Granada: Grupo Editorial Universitario.

Morin, E. (1999). Seven complex lessons in education for the future. France: UNESCO

OCDE. (2012). Perspectives OCDE: México Reformas para el Cambio [Mexico reforms for change]. 2012. Retrieved April 18, from bit.ly/1KwedYX.

Oppenheimer, A. (2011). ¡Basta de historias! La obsesión latinoamericana con el pasado y las 12 claves del futuro [No more stories! The Latin American obsession with the past and the 12 keys to the future]. México: Debate.

Schmelkes, S. (1997). La calidad en la educación primaria: un estudio de caso [The quality of elementary school: a case study]. México: Fondo de Cultura Económica.

Schön, D. A. (1987). Educating the reflective practitioner: Toward a new design for teaching and learning in the professions. San Francisco: Jossey-Bass.

SEP (2013). Censo de Escuelas, Maestros y Alumnos de Educación Básica y Especial [Census of schools, teachers and students of basic and special education]. Retrieved October 14, 2014, from bit.ly/1pwSyNK.

SEP (2014). ENLACE 2014. Retrieved October 14, 2014, from http://bit.ly/1MkqBTF.

Tirado, F. (1990, March-April). La calidad de la educación básica en México [The quality of elementary school in Mexico]. Ciencia y desarrollo, XVI(91), 59-69.

Tobón, S. (2004). Formación basada en competencias. Pensamiento complejo, diseño curricular y didáctica [Competencies-based training. Complex thinking, curriculum design and teaching]. Bogotá: Ecoe. 
